\title{
Ermenistan'da Yerel Yönetimler ve Bölgesel Politikalar
}

Husik Ghulyan*

Öz: Makalede Ermenistan'in yerel yönetimler ve bölgesel politikalarl incelenmektedir. Ilk önce Ermenistan'da yerel yönetimlerin gelişimi ve ülkenin idari yapllanmasında yerel yönetimlerin rolü ve yeri incelenmiştir. Makalede Ermenistan'in yerel yönetimler sistemi, Avrupa Yerel Yönetimler Özerklik Şartı (AYYÖS) băglamında ve yerel yönetimler mevzuatının bu şartın ilkelerine ve maddelerine uyum sağlayıp sağlamaması açısından incelenmektedir. Bu amaç doğrultusunda Ermenistan anayasası, belediye mevzuatı ve diğer yasalar incelenmiş ve onlarda Ermenistan tarafindan onaylanmış olan AYYÖŞ’ün maddeleri ne derecede yansitıldĭ̆ incelenmiştir. Ayrıca, sosyoekonomik gelişmişlik açısından önemli bölgelerarası dengesizliklere sahip olan Ermenistan'da, bu dengesizlikleri ortadan kaldırmak ve azaltmak için ülkenin geliştirdiği politikalar ve düzenlemeler ve onların sonuçlart incelenmektedir.

Anahtar Kelimeler: Ermenistan, yerel yönetimler, AYYÖŞ, bölgesel politika.

\section{Local Governments and Regional Policies in Armenia}

Abstract: In this paper, local governments and regional policies of the Republic of Armenia are examined. First, the development of local governance in Armenia and the role and place of local governments in the governance structure of this country have been analyzed. In the paper, Armenia's local government system in the context of ECLSG and the correspondence of Armenia's local governance legislation to the principles and clauses of this charter are analyzed. In line with this objective, the Constitution of the Republic of Armenia, its municipal legislation and other statutes have been analyzed, and the reflection of the ECLSG clauses ratified by Armenia in these statutes is examined. In addition, the regional policies and regulations aiming at the elimination of Armenia's inter-regional differences in terms of development and their results are examined.

Keywords: Armenia, local government, ECLSG, regional policy.

\footnotetext{
*Doktora Öğrencisi, Ankara Üniversitesi, Sosyal Bilimler Enstitüsü, 06590 Cebeci/Ankara/Türkiye.

Makale gönderim tarihi:31.01.2015

Makale kabul tarihi:09.06.2015
}

Çă̆daş Yerel Yönetimler, Cilt 24 Sayı 3 Temmuz 2015, s.93-115. 


\section{Giriş}

Piyasa ekonomisine ve demokratik ilkelere dayanan siyasi sisteme geçiş yapan, başka bir deyişle "geçiş" döneminde bulunan Ermenistan'da yerel yönetimlerin geliştirilmesi büyük önem arz etmektedir. Ayrıca dünyada kamu yönetimi alanında yerinden yönetim ve adem-i merkeziyetçilik süreçlerinin gün geçtikçe önem kazanması, eskiden yerel yönetimlere sahip olmayan Ermenistan'da bu konunun daha aktüel ve güncel bir sorun olarak ortaya çıkmasını sağlamıştır.

Belirtmemiz gerekir ki, Ermenistan'da post-Sovyet dönemindeki yerel yönetimlerin gelişimi (Saroyan,2010; Babajanian, 2008) ve gerçekleştirilen reformlar (Tumanyan, 2001a; Local Self-Government in Armenia, 2008; Local Self-Government in Armenia, 2011), yerinden yönetim veya desantralizasyon (Babajanian, 2008a; Saroyan, 2010; Hovasapyan, 2005), yerel yönetimlere sivil toplumun katılımı (Doane vd., 2000; Saroyan, 2010), yerel yönetimlerde enformel ilişkiler (Margaryan, 2011), merkezi yönetim ile bölgesel ve yerel yönetimler arasındaki ilişkiler (Doane vd., 2000; Tumanyan, 2001b), yerel yönetimlerde saydamlık, sorumluluk, yönetişim (Doane vd.,2000; Saroyan, 2010; Babajanian, 2008b), yerel maliye sistemi (Choginyan, 2007) konularında çok sayıda araştırmalar gerçekleştirilmiştir. 2005 yılında Ermenistan, Anayasası'nda, sonraki dönemlerde ise yerel yönetimler mevzuatında değişiklikler yaparak onlar ile Avrupa Yerel Yönetimler Özerklik Şartı (AYYÖŞ) arasında uyum sağlamaya çalışmıştır. Dolayısıyla, bahsi geçen konuların artık AYYÖŞ bağlamında incelenmesine yol açılmıştır. Ama bu bağlamda var olan araştırmaların bir kısmı (Hovasapyan, 2005) ya uyum sağlama sürecinin ilk aşamalarını incelemektedir, bir başka deyişle kısa bir dönemi kapsamaktadır ve daha çok tavsiyede bulunma boyutundadır; diğer kısmı ise (Akelyan, 2011) sürecin daha uzun bir dönemi ele alınarak bir boyutunu (yerinden yönetimin maliye boyutları) incelemektedir. Yani var olan çalışmalar çok kapsaycı değildir. Dolayısıyla, AYYÖŞ bağlamında Ermenistan kamu yönetimi sisteminde yerinden yönetim süreçlerinin daha kapsayıcı olarak incelenmesi güncel ve önemli konu haline gelmektedir.

Güncel olan diğer bir konu ise, bağımsızlıktan sonra ekonomik ve sosyal zorluklar yaşayan ve bu bağlamda bölgeler arasında önemli ekonomik ve sosyal dengesizliklere sahip olan Ermenistan'da bölgesel politikaların incelenmesidir. Özellikle Ermenistan'daki yerinden yönetim süreçleri ile ilgili çok sayıda araştırma ve inceleme bulunsa bile, Ermenistan'da bölgesel politikalar konusunda böyle bir durumdan bahsetmek zordur ve bu konunun incelenmesi de güncelliğe sahiptir. 


\section{Ermenistan'da Yerel Yönetimler}

Ermenistan Anayasası'nın kabul edilmesinden (5 Haziran 1995) sonra Ermenistan kamu yönetimi sisteminde ilk kez yerel yönetim sistemi kurulmuştur (Saroyan, 2010: 1). Vurgulamak gerekir ki hem Ermenistan 1. Cumhuryeti hem de Ermenistan Sovyet Cumhuriyeti'nde yerel yönetim sistemi bulunmamaktaydı. Ermenistan Sovyet Cumhuriyeti'nin idari yapısının birimleri idari bölgeler, kentler, kentsel bölgeler, kasabalar ve köylerden oluşmaktaydı (bkz. Tablo 1).

Tablo 1. Ermenistan Sovyet Cumhuriyeti'nin İdari Birimleri

\begin{tabular}{|l|l|}
\hline Bölgeler & 37 \\
\hline Kentler & 27 \\
\hline Cumhuriyet statüsüne sahip olan kentler & 22 \\
\hline Bölgesel statüye sahip olan kentler & 5 \\
\hline Kentsel bölgeler & 10 \\
\hline Kasabalar & 31 \\
\hline Köyler & 479 \\
\hline
\end{tabular}

Kaynak: Dudarev ve Evseeva, 1987: 14.

O dönemde yerleşim yerlerine, kendi gelişme perspektifleri ve ülkedeki önemi dikkate alınarak statü verilmekteydi. Bu statüye göre, merkezi yönetim ve finansman çerçevesinde yerleşim yerlerine finansman ve kaynaklar tahsis edilmekteydi. Bölgelerde yerel konseyler ve onların yürütme organları bulunmaktaydı. Bu konseyler ise kendi bölgelerinde merkezi yönetimin taşra uzantısıydı ve yasalarla kendilerine verilen görevleri yerine getirmekteydiler. $\mathrm{Bu}$ sistem 1995 yılına kadar yürürlükte kalmıştır. Ermenistan Anayasası ve Ermenistan Cumhuriyeti İdari Taksimatı Hakkında Kanununa göre Ermenistan 10 bölgeye ayrıldı ve başkent Erivan'a da bölge statüsü verildi. Bölgeler şehir ve köy belediyelerine, Erivan ise mahalle belediyelerine ayrıldı (Tumanyan, 2001a: 327).

Bugün, Ermenistan'da sadece belediyeler düzeyinde yerel yönetimler bulunmaktadır. Her şehir veya köy belediyesi bir ya da birkaç yerleşim yerinden oluşmaktadır. Ermenistan'daki 1000 yerleşim yeri 918 belediyede birleştirilmektedir. Bunlardan 49'u şehir, 866's1 ise köy belediyesidir. Bir büyükşehir belediyesi olan başkent Erivan ise 12 şehir belediyesine ayrilmaktadır (Tumanyan, 2001b).

27 Kasım 2005 yılında Ermenistan Anayasası'nda değişiklikler yapılmış ve bu değişiklikler yerel yönetimleri şu şekilde etkilemiştir:

a) Belediyelerin (görevlendirilmiş) görevlerini yerine getirebilmesi için devlet bütçesinden belediyelere zorunlu finansman sağlanmış ve belediyeler 
tarafından yerel vergilerin ve sunulan hizmetler karşılığında belli ödemelerin yapılması hakkı tanınmıştır (Madde 106),

b) Yerel yönetim organlarının görev süresi 4 yıl olarak belirlenmiştir (Madde 107),

c) Erivan'a belediye statüsü verilmiştir (Madde 108),

ç) Merkezi hükümet tarafından herhangi bir belediye başkanının görevinden uzaklaştırması için Anayasa Mahkemesinin görüşünün alınması zorunluluğu getirilmiştir (Madde 109),

d) Kamu yararı amacıyla belediyelerin birleșebilmeleri ya da birbirinden ayrılabilmeleri, ayrıca belediyeler arası birlikler kurulabilmeleri öngörülmüştür (Madde 110).

27 Kasım 2005'te Ermenistan Anayasası'nın 7. Bölümünde ('Yerel Yönetimler' başlıklı bölüm) yapılan değişikliklerin amacı yerel yönetim sisteminin iyileştirmesi, demokratikleştirmesi ve yasalar ile AYYÖŞ’nın kuralları arasında uyum sağlanmasıydı. Ermenistan, AYYÖŞ’na 2001 yılında imza koymuş, 2002 yılında ise Ermanistan Parlamentosu tarafindan onaylanmıştır (Akelyan, 2011: 20).

Ermenistan Cumhuriyeti'nin "Yerel Yönetimler Hakkında Kanunu" (07.05.2002 tarihinde kabul edilmiştir) Anayasanın yukarıda değinilen 7. bölümüne dayanır. Bu yasada, "Ermenistan Cumhuriyeti'nde yerel yönetim kavramı, yerel yönetimin ilkeleri, yetkileri ve yasal, ekonomik, finansal temelleri ve güvenceleri tanımlanmakta ve merkezi ve yerel yönetimler arasındaki karşılıklı ilişkiler düzenlenmektedir”. Bu yasaya göre (Madde 9) Ermenistan'da yerel yönetim sisteminin ilkeleri şunlardır:

1. Belediyelerin menfaatleri ile ilgili herhangi bir faaliyette bulunması için genel yetki hakk1,

2. Yerel yönetimin çalışmalarında özerklik ve sorumluluk,

3. Belediyelere yasalarla verilen yetkileri gerçekleştirmek için gerekli finansal kaynakların sağlanması,

4. Merkezi yönetimin yetkilerinin yerel yönetimlere devredilmesi. Bu yetkiler yerel birimler tarafından daha verimli gerçekleştirilebilir ise, bunların yerine getirilmesi için yeterli finansal araçların sağlanması.

5. Belediyelerin haklarının, menfaatlerinin ve mallarının yasaların öngördüğü şekilde korunması,

6. Mali açıdan zayıf belediyelere mali düzenlemeler aracılığıyla yardım yapilmasi,

7. Bazı sorunları çözmek amacıyla yasalarla belirlenmiş şekilde diğer belediyelerle birlikte belediyelerarası birliklerin oluşturulması, 
8. Belediye sınırları içinde yaşayan halka karşı sorumluluk,

9. Yerel yönetimlerde faaliyetlerin saydamlığı.

Görüldüğü üzere AYYÖŞ’nın ilkelerinin çoğu Ermenistan Yerel Yönetimler Kanununa da yansımıştır. Aynı zamanda, Ermenistan, AYYÖŞ’nda bulunmayan, fakat bu Şart'a aykırı olmayan, kendi yerel yönetim sistemine özgü ilkeler de eklemiştir.

Ermenistan'da yerel yönetim organları, belediye meclisi ve belediye başkanıdır. Ermenistan'ın yerel yönetim sistemi ve yapısı şematik olarak Resim 1 'de gösterilmiştir.

Şekil 1. Ermenistan Cumhuriyeti yerel yönetim sisteminin örgüt yapısı

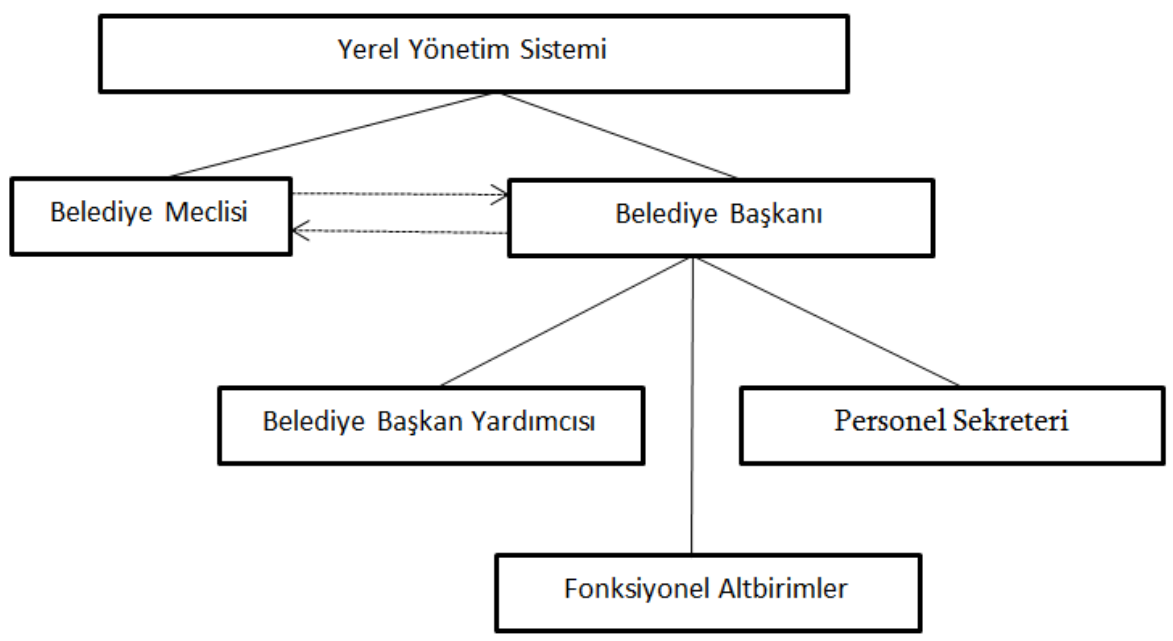

Belediye Başkanı yürütme organı ve aynı zamanda resmi olarak belediyeyi temsile yetkili kişidir (Saroyan, 2010: 2). 25 yaşından büyük, ilgili belediyenin sınırları içerisinde en az 1 yıl süre ile ikamet eden, en az ortaokul eğitimini tamamlamış olan herkes belediye başkanı olabilir. Belediye başkanı 4 yıl süreyle seçilir. Belediye başkanı kendi yetkilerinin bir kısmını doğrudan, bir kısmını ise belediye meclisi ile birlikte kullanmaktadır. Belediye başkanı belediye gelişme programını, personelin ve birimlerin bütçesini yapısını, yerel halk oylaması gerçekleştirme önerilerini belediye meclisine sunar. Belediye meclisi temsili organdır ve kendi görevlerini oturumlar aracılığıyla yapmaktadır (The Law of the Republic of Armenia on Local Self-Government, 2014).

\section{AYYÖŞ ve Ermenistan Mevzuatı}

Bağımsızlığa ulaştıktan sonra Ermenistan, demokratikleşme ve devlet kurumlarını geliştirme sürecine başladı. Sovyetler Birliği'nin parçası olan ve 
demokratik bir sistem inşa etmekte herhangi bir tecrübeye sahip olmayan Ermenistan tek başına yeni sistemin zorluluklarını ortadan kaldıramazdı. Dolayısıyla etkili reformlar gerçekleştirmesi için Ermenistan diğer ülkelerin tecrübesinden yararlanma yoluna gitti. Diğer taraftan, uluslararası toplum tarafindan yeni devletin uluslararası alanda tanınması Ermenistan'a farklı uluslararası örgütlerde üyelik sağladı. Yerel yönetim sistemi geliştirme açısından, Ermenistan'ın Avrupa Konseyi üyeliği en önemli gelişmelerden biriydi. Ermenistan 2001 y1lında Avrupa Konseyi üyesi olduktan hemen sonra, ona AYYÖŞ'nı (bundan sonra 'Şart') imzalaması ve onaylaması ve kendi mevzuatında ve kurumlarında ilgili değişiklilikleri yapması önerildi (Akelyan, 2011: 20).

Dolayısıyla, Ermenistan'da yerel yönetimler ile ilgili mevzuatın oluşturmasında Şart rehber olarak kabul edilmiștir. Ermenistan Anayasası'nın 6. maddesine göre, onaylanmış uluslararası antlaşmalar ulusal mevzuattan üstündür. Bu yüzden, Ermenistan 11 Mayıs 2001 yılında Şart'1 imzaladığı ve 25 Ocak 2002 yılında onayladığı için kendi mevzuatı ile bu Şart arasında uyum sağlamaya başlamıştır.

Ayrıca; Şart, onu onaylamış olan devletleri, yerel yönetimlerinin siyasal, yönetsel ve akçal yönlerden özerkliklerini güvence altına almaya zorlayıcı kurallar içermektedir (Keleş ve Mengi, 2013: 77). Bütün bu nedenlerden dolayı, Ermenistan yerel yönetimler mevzuatında Şart'ın hangi ilkelerinin bulunduğuna değinmek yerinde olacaktır.

Şart'in 2. maddesine göre "Özerk yerel yönetimler ilkesi ulusal mevzuat ile uygun olduğu durumlarda anayasa ile tanınacaktır". Ermenistan mevzuatına bu ilke tamamıyla yansımış durumdadır. Örneğin, Anayasası'nın 11. maddesinin 2. fikrasina göre "Ermenistan Cumhuriyeti yerel yönetimleri güvence altına almaktadır". Ayrıca Anayasanın 7. bölümü tamamıla yerel yönetimlere ayrılmış ve bu bölüme yerel yönetimlerin temel kavramları ve ilkeleri yansıtılmıştır. Şart tarafindan önerilmiş yerel yönetimin ilkeleri ise, yukarıda gördüğümüz gibi, "Yerel Yönetimler Hakkında Kanunu"nun 9. maddesinde yer almaktadir.

Şart'ın 3. maddesine göre yerel yönetimler kavramı şu şekilde tanımlanır:

“ 1- Özerk yerel yönetim kavramı yerel yönetimlerin, kanunlarla belirlenen sınırlar çerçevesinde, kamu işlerinin önemli bir bölümünü kendi sorumlulukları altında ve yerel nüfusun çıkarları doğrultusunda düzenleme ve yönetme hakkı ve imkanı anlamını taşır.

2- Bu hak, doğrudan, eşit ve genel oya dayanan gizli seçim sistemine göre serbestçe seçilmiş üyelerden oluşan ve kendilerine karşı sorumlu yürütme organlarına sahip olabilen meclisler veya kurullar tarafından kullanılacaktır. Bu hüküm, mevzuatın olanak verdiği durumlarda, vatandaşlardan oluşan meclislere, referandumlara veya vatandaşların doğrudan katılımına olanak veren öteki yöntemlere başvurulabilmesini hiçbir şekilde etkilemeyecektir." 
2005 yılındaki Anayasa değişikliği sürecinde, Şart'1n 3. maddesinin 1. fikrası da benimsenmiş ve halihazırdaki Anayasanın 104. maddesinde "Özerk yerel yönetim, belediyenin, Anayasa ve kanunlar gereğince yerel öneme sahip sorunları, kendi sorumlulukları altında ve yerel nüfusun refahı doğrultusunda çözme hakkı ve yetkisidir." şeklinde tanımlanmıştır.

Şart'in bu maddesinin 2. fikrası ise Anayasanın 107. maddesinde yer almaktadır. Anayasa'nın 107. maddesine göre, Ermenistan'da yerel yönetim organları belediye meclisi ve belediye başkanıdır. Belediye meclisi karar, belediye başkanı ise yürütme organı olarak tanımlanmaktadır. Anayasanın 4 . maddesine göre ise, yerel yönetimlerin organları doğrudan, eşit ve genel oya dayanan gizli seçim sistemine göre serbestçe seçilmektedir.

Vatandaşların yerel yönetime katılımını sağlayan öteki yöntemlerden ise, Ermenistan mevzuatında sadece yerel referandum gerçekleştirme hakkı tanınmıştır (Anayasanın107. maddesinin 4. fikrası). Anayasaya göre ise yerel referandum gerçekleştirme yöntemi Ermenistan Cumhuriyeti 'Yerel Referandum Hakkında Kanun' ile tanımlanır.

Burada belirtmelidir ki, Şart'1n 3. maddesinin 1. fikrası ne kadar Ermenistan mevzuatına yansımış olsa ve onun aracılığıyla yerel yönetimlerin yetki genişliği tanınsa da, Ermenistan'da yerel yönetimlerin merkezi yönetim ile yerel yönetimler arasındaki güç paylaşımında fiilen çok zayıf olması, yasaların uygulanmasina fazla imkan vermemektedir.

Şart'ın 4. maddesinde yerel yönetimlerin yetkileri ve sorumlulukları tanımlanmaktadır. Buna göre:

"1-Yerel yönetimlerin temel yetki ve sorumlulukları anayasa ya da kanun ile belirlenecektir. Bununla beraber, bu hüküm yerel yönetimlere kanuna uygun olarak belirli amaçlar için yetki ve sorumluluklar verilmesine engel teşkil etmeyecektir.

2-Yerel yönetimler, kanun tarafından belirlenen sınırlar içerisinde, yetki alanlarının dışında bırakılmış olmayan veya başka herhangi bir makamın görevlendirilmemiş olduğu tüm konularda faaliyette bulunmak açısından tam takdir hakkına sahip olacaklardır.

3-Kamu sorumlulukları genellikle ve tercihan vatandaşa en yakın olan yönetim kademesi tarafından kullanılacaktır. Sorumluluğun bir başka yönetim kademesine verilmesinde, görevin kapsam ve niteliği ile yetkinlik ve ekonomi gerekleri gözönünde bulundurulmalıdır.

4-Yerel yönetimlere verilen yetkiler normal olarak tam ve münhasırdır. Kanunda öngörülen durumların dışında, bu yetkiler öteki merkezi veya bölgesel yönetimler tarafindan zayıflatılamaz veya sinırlandırılamaz.

5-Yerel yönetimlerin merkezi veya bölgesel bir yönetim tarafından yetkilendirildiği durumlarda, bu yetkilerin yerel koşullara uygun olarak kullanılabilmesinde yerel yönetimlere olanaklar ölçüsünde takdir hakkı tanınacaktır.

6- Yerel yönetimleri doğrudan ilgilendiren tüm konulara ilişkin planlama ve karar alma süreçleri içinde, kendilerine, olanaklar ölçüsünde, zamanında ve uygun biçimde danışılacaktır." 
Ermenistan'da yerel yönetim organlarının yetkileri 'Yerel Yönetimler Hakkında Kanun'la tanımlanır (madde 32-45). Ermenistan mevzuatında yerel yönetimlerin yetkilerini tanımlayan başka yasalar da bulunmaktadır. Örneğin 'Okul Öncesi Eğitim Hakkında Kanun'la bu alanda yerel yönetimlerin yetkileri tanımlanmaktadır (madde 17). Yerel yönetimlerin yetkileri 'Katı Atıklar Hakkında Kanun'la da tanımlanmaktadır (madde 11). Şehircilik alanında yerel yönetimlerin yetkileri "Şehircilik Hakkında Kanun"la tanımlanır (madde 11).

Yerel yönetimlerin faaliyet özgürlüğü 'Yerel Yönetimler Hakkında Kanun'un 10. maddesinin 8. fikrasında tanımlanmıştır: "Yerel Yönetimler, kanunlara aykırı olmayacak şekilde, belediye menfaatleriyle ilgili herhangi bir konuda faaliyette bulunabilirler." Ermenistan Anayasası'nın 105. maddesine göre, devlet organları yetkilerini, daha verimli gerçekleştirmek amacıyla ve yasalar yoluyla yerel yönetimlere devredebilirler. $\mathrm{Bu}$, ayrıca yerel yönetimlerin ilkelerinden birisidir ve 'Yerel Yönetimler Hakkında Kanun'un 9. maddesinde yer almaktadır.

Yerel yönetimlere verilen yetkilerin tamlığ 1 ve münhasırllğ 1 ise aynı yasanın 71. maddesinde yer almaktadır. Bu maddeye göre yetkili olan devlet organı (Bölgesel Yönetim Bakanlığı) ve ilgili vali, yerel yönetimlerin kararlarına, faaliyetlerine ve görevlerini ihmaline sadece mahkeme yoluyla itiraz edebilirler. Ayrıca, aynı yasanın 70. maddesinde merkezi yönetim organlarının yerel yönetimlerin yetkilerini onların yerine geçerek gerçekleştirmesi yasaklanmaktadır.

Bilindiği üzere, Şart'ın 4. maddesinin 6. paragrafı Türkiye'nin çekince koyduğu paragraftır. Yerel yönetimler ile ilgili olan Ermenistan yasaları incelendiğinde aynı çekincenin Ermenistan tarafindan da konulduğu ve Ermenistan yasalarında da bu maddeyi yansitan yasal düzenlemeler bulunmadığ1 görülmektedir. Yerel yönetimleri doğrudan ilgilendiren tüm konulara ilişkin planlama ve karar alma süreçleriyle ilgili olarak yerel yönetimlere kendi olanakları doğrultusunda, zamanında ve uygun biçimde danışılması Ermenistan Anayasası'nın 110. maddesinde kısmen tanımlanmaktadır. Bu maddeye göre, "Belediyeler kamu yararı açısından bütünleşebilir ya da birbirinden ayırılabilirler. Parlamento, ilgili yasayı hükümetin önerisiyle kabul etmektedir. Bunun öncesinde hükümet ilgili belediyelerde yerel referandumlar gerçekleştirilmesini belirler ve yerel referandumların sonuçları yasal girişimlere eklenir. Belediyeler, yerel referandumların sonuçları hesaba katılmadan birleşebilir ya da ayrılabilirler." Görüldüğü gibi, bu maddede yerel referandumdan söz edilmektedir. Buna rağmen halkın iradesini ifade eden yerel referandumun sonuçları hesaba kat1lmayabilir. 
Ayrıca Şart'ın 5. maddesine göre "Yerel yönetimlerin sınırlarında, mevzuatın elverdiği durumlarda ve mümkünse bir referandum yoluyla ilgili yerel topluluklara önceden danışılmadan değişiklik yapılamaz." Yukarıda görüldüğü gibi, Ermenistan Anayasası'nın 110. maddesi Şart'1n bu maddesine uymamaktadır.

\section{Şart'ın 6. maddesine göre:}

"1-Kanunla düzenlenmiş daha genel hükümlere halel getirmemek koşuluyla, yerel yönetimler kendi iç idari örgütlenmelerini, bunları yerel ihtiyaçlarla uyumlu kılmak ve etkin idare sağlamak amacıyla, kendileri kararlaştırabileceklerdir.

2-Yerel yönetimlerdeki görevlilerin çalışma koşulları liyakat ve yeteneğe göre yüksek nitelikli eleman istihdamına imkan verecek ölçüde olmalıdır; bu amaçla yeterli eğitim olanaklarıyla ücret ve mesleki ilerleme olanakları sağlanmalıdır."

Bilindiği üzere Şart'ın 6. maddesinin 1. fikrasına Türkiye tarafından çekince konulmuştur. Ermenistan'a gelince Şart'ın 6. maddesine tümüyle çekince konulduğu belirtilmelidir.

Şart'in 7. maddesine göre:

"1. Yerel düzeyde seçilmiş temsilcilerin görev koşulları görevlerin serbestçe yerine getirilmesi olanağını sağlayabilmelidir.

2. Görev koşulları söz konusu görevin yürütülmesi sırasında yapılacak masrafların uygun biçimde karşılanmasıyla birlikte, uygunsa, kazanç-kaybının telâfi edilmesine veya yapılan işin karşılığında ücret ve buna karşılık gelen sosyal sigorta primlerinin ödenmesine olanak sağlayacaktır.

3. Yerel olarak seçilmiş kişilerin görevleriyle bağdaşmayacak işlev ve faaliyetler kanunla veya temel hukuk ilkelerine göre belirlenir" ${ }^{1}$

Ermenistan, Şart'1n bu maddesinin sadece 1. ve 3. paragraflarını onaylamıştır.

Şart'1n 8. maddesiyle yerel yönetimlerin faaliyetlerinin idari yönden gözetim ve denetimi belirlenmektedir:

“1- Yerel yönetimlerin idari açıdan her türlü gözetim ve denetimi ancak kanunla veya anayasa ile belirlenmiş durumlarda ve yöntemlerle gerçekleştirilebilir.

2- Yerel yönetimlerin faaliyetlerinin idari gözetim ve denetimi normal olarak sadece kanunla ve anayasal ilkelere uygunluk sağlamak amacıyla yapılacaktır. Bununla beraber, üst makamlar yerel yönetimleri yetkili kıldıkları işlerin gerektiği gibi yapılıp yapılmadığını görmek üzere yerindelik denetimine tabi tutabileceklerdir.

3- Yerel yönetimlerin idari gözetim ve denetimi, denetleyen makamın müdahalesi ile korunması amaçlanan çıkarların önemiyle orantılı olarak sınırlandırılmasını sağlayacak biçimde yapılmalıdır"

Ermenistan Anayasası'nın 108. maddesinin 1. fikrası ile yerel yönetimlerin yasal olarak denetlenmesinin sistemi belirlenmiştir. Bu maddede yerel

\footnotetext{
${ }^{1}$ Türkiye'nin çekince koyduğu paragraf.

${ }^{2}$ Türkiye'nin çekince koyduğu paragraf.
} 
yönetimlerin görevlerinin yerine getirilip getirilmemesinin idari denetiminin yasayla belirleneceği söyleniyor. Anayasa'nın bu maddesine dayanarak 'Yerel Yönetimler Hakkında Kanun'un 4. bölümünde, yerel yönetimlerin idari gözetim ve denetimi için ayrıntılı bir madde düzenlenmiștir (Madde 77). Yerel yönetimlerin denetlenmesiyle ilgili maddeler 'Denetleme Odas1 Hakkında Ermenistan Cumhuriyeti Kanunu'nu da içermektedir. Ayrıca şu da belirtilmelidir ki, Şart'in 8. maddesinin 3. paragrafina Ermenistan tarafindan çekince konmamasına rağmen, Ermenistan mevzuatı hem bu paragrafa uyum sağlamamış, hem de bu konuda uyum sağlama girişimlerinde bulunmamıştır. Şart'in 9. maddesiyle yerel yönetimlerin finansman kaynakları belirlenmektedir:

“1- Ulusal ekonomik politika çerçevesinde, yerel yönetimlere kendi yetkileri dahilinde serbestçe kullanabilecekleri yeterli mali kaynaklar sağlanacaktır.

2- Yerel yönetimlerin mali kaynakları anayasa ve kanunla belirlenen sorumluluklarla orantılı olacaktır.

3- Yerel yönetimlerin mali kaynaklarının en azından bir bölümünü, oranlarını kendilerinin kanunun koyduğu sınırlar dahilinde belirleyebilecekleri yerel vergi ve harçlardan sağlanacaktır.

4- Yerel yönetimlere sağlanan kaynakların dayandığı mali sistemler, görevin yürütülmesi için gereken harcamalardaki gerçek artışların mümkün olduğunca izlenebilmesine olanak tanımaya yetecek ölçüde çeşitlilik arz etmeli ve esneklik taşımalıdır. ${ }^{3}$

5- Mali bakımdan daha zayıf olan yerel yönetimlerin korunması, potansiyel mali kaynakların ve karşılanması gereken mali yükün eşitsiz dağılımının etkilerini ortadan kaldırmaya yönelik mali eşitleme yöntemlerinin veya buna eş önlemlerin alınmasını gerektirir. Bu yöntemler ve önlemler yerel yönetimlerin kendi sorumluluk alanlarında kullanabilecekleri takdir hakkını azaltmayacaktır.

6- Yeniden dağıtılan kaynakların yerel yönetimlere tahsisinin nasıl yapılacağı konusunda, kendilerine uygun bir biçimde danışılacaktır. ${ }^{4}$

7- Mümkün olduğu ölçüde, yerel yönetimlere yapılan hibeler belli projelerin finansmanına tahsis edilme koşulu taşımayacaktır. Hibe verilmesi yerel yönetimlerin kendi yetki alanları içinde kendi politikalarına ilişkin olarak takdir hakkı kullanmadaki temel özgürlüklerine halel getirmeyecektir. ${ }^{5}$

8- Yerel yönetimler sermaye yatırımlarının finansmanı için kanunla belirlenen sınırlar içerisinde ulusal sermaye piyasasına girebileceklerdir."

Anayasasının 106. maddesinde belediyelerin gelir kaynaklarının yasayla belirleneceği belirtilmektedir. 'Yerel Yönetimler Hakkında Kanun'un 57. maddesiyle yerel yönetimlerin mali kaynakları belirlenmektedir. Ayrıca bu kanunun 9. maddesinde belediyelere verilmiş yetkilerin ve onların yerine

\footnotetext{
${ }^{3}$ Türkiye'nin çekince koyduğu paragraf.

${ }^{4}$ Türkiye'nin çekince koyduğu paragraf.

${ }^{5}$ Türkiye'nin çekince koyduğu paragraf.
} 
getirilebilmesi için gerekli mali kaynakların orantılı olmasından söz edilmektedir. Bu, Ermenistan'da yerel yönetim ilkelerinden birisidir. Anayasa'nın 106. maddesinde yerel yönetimlere verilmiş yetkilerin zorunlu finasmanı belirlenmektedir. Buna göre, yasada yerel yönetimlerin ilkelerinden birisine yer verilmiştir: devlet organlarının yetkileri, bu yetkiler belediyeler tarafından daha verimli şekilde gerçekleştirilecek olduğu takdirde, belediyelere devredilmektedir. Daha ayrıntılı olarak bakıldığı zaman, Şart'ın bu maddesinin fikralarının, ayrıca 'Yerel Yönetimler Hakkında Kanun'un (madde 58, 59), 'Vergiler Hakkında Kanun'un (maddeler 2, 3, 7), 'Maliye Ayarlama Hakkında Kanun'un (madde 7) farklı maddelerinde de yer aldığı görülebilir.

Şart'1n 10. maddesinde yerel yönetimlerin birlikler kurma ve birliklerden ayrılma hakkı tanımlanmaktadır:

"1- Yerel yönetimler yetkilerini kullanırken, ortak ilgi alanlarındaki görevlerini yerine getirebilmek amacıyla, başka yerel yönetimlerle işbirliği yapabilecekler ve kanunlar çerçevesinde birlikler kurabileceklerdir.

2- Her devlet, yerel yönetimlerin ortak çıkarlarının korunması ve geliştirilmesi için birliklere üye olma ve uluslararası yerel yönetimleri birliklerine katılma hakkını tanıyacaktır.

3- Yerel yönetimler, kanunla öngörülen koşullarda, başka devletlerin yerel yönetimleriyle işbirliği yapabilirler" 6

Ermenistan Anayasası'nın 110. maddesinde, belediyelerin kamu yararı açısından yasalar gereğince birleşebileceği ya da birbirinden ayrılabileceği ve belediyelerarası birlikler oluşturulabileceği gösterilmiştir. Bu maddeye göre, belediyeler kamu yararı açısından bütünleşebilir ya da birbirinden ayırılabilirler. Bunun için Parlamento, ilgili yasayı hükümetin önerisiyle kabul etmelidir. Bundan önce, hükümet ilgili belediyelerde yerel referandumlar düzenler. Yerel referandumların sonuçları, hükümetin Parlamento'ya sunduğu yasa önerisine eklenir. 'Ermenistan Cumhuriyeti Yerel Yönetimler Hakkında Kanun'un 8. bölümünde, belediyelerarası birlikler, bu birliklerin oluşturma hakkı, yöntemi ve birlik organları tanımlanmaktadır (Maddeler 78-80). Ama, Şart'in bu maddesinin 3. fikrasına Türkiye gibi Ermenistan da çekince koymuştur.

Şart'ın 11. maddesi yerel yönetimlerin yasal korunmasını tanımlamaktadır: 'Yerel yönetimler kendi yetkilerinin serbestçe kullanımı ile anayasa veya ulusal mevzuat tarafindan belirlenmiş olan özerk yönetim ilkelerine bağlı kalmanın sağlanması amacıyla yargı yoluna başvurma hakkına sahip olacaklardır.,

Ermenistan Cumhuriyeti'nin 'Yerel Yönetimler Hakkında Kanun'unda, yerel yönetimlerin bazı durumlarda mahkemeye başvurabilmesi belirlenmiştir. Özellikle yasanın 14. maddesine göre belediye meclisinin kararlarına, belediye

\footnotetext{
${ }^{6} 2$. ve 3. paragrafları Türkiye'nin çekince koyduğu paragraflardır.

${ }^{7}$ Türkiye'nin çekince koyduğu paragraf.
} 
başkanı mahkemeye başvurarak itirazda bulunabilir. Aynı şekilde, belediye başkanının kararlarına da belediye meclisi mahkeme aracılığıyla itirazda bulunabilir. Kanunun 71. maddesine göre, yerel yönetimler haklarını ihlal eden devlet organları, yönergeleri ve direktifleri ile ilgili olarak mahkemeye başvurabilirler.

Görüldüğü gibi Ermenistan Cumhuriyeti'nin yerel yönetimler mevzuat1, genel olarak, AYYÖŞ’ndaki maddelere uyum sağlamış durumdadır. Buna karşın, Ermenistan mevzuatında çok sayıda eksiklikler de bulunmaktadır ve maalesef yıllardır bunlara çözüm bulunmamaktadır. Zira bu eksiklikleri çözmek için ciddi ve hedeflenmiş faaliyetler gerçekleştirilmemektedir. Örneğin 'Yerel Yönetimler Hakkında Kanun'a göre (madde 59) belediyeler kendi altyapılarını geliştirmek gibi girişimler için yasalarla belirlenmiş şekilde kredi anlaşmaları yapma hakkına sahiptir; ama şimdiye kadar bunun için yasal düzenlenme yapılmamıştır ya da yukarıda görüldüğü üzere, Anayasaya göre belediyeler birleşebilirler ya da birbirinden ayırılabilirler, ama bunun yöntemiyle ilgili yasa hala çıkarılmamıştır. Ayrıca 'Yerel Yönetimler Hakkında Kanun'unda belediyelerarası birlikler oluşturma hakk1, yöntemi ve birliğin organları tanımlanmaktadır. Fakat bu tür birliklerin organlarının yetkileri ve bu organların oluşturulma yöntemi tanımlanmamıştır.

Türkiye ile karşılaştırdığımızda ise, görüldüğü gibi, Şart'ın Türkiye tarafindan çekince konulduğu maddelerin çoğuna Ermenistan da ya çekince koymuş ya da açık şekilde çekince koyduğunu dile getirmeyip mevzuatı ile Şart'ın ilgili maddeleri arasında uyum sağlamamıştır. Diğer önemli husus ise, Ermenistan'da yerel yönetimlerin, merkezi hükümet ile yerel yönetimler arasındaki güç paylaşımında fiilen çok zayıf olmasıdır. Şart'ın maddeleri her ne kadar Ermenistan mevzuatına yansımış olsa ve onun aracılığıyla yerel yönetimlere yetki genişliği tanınmış olsa da, yerel yönetimlerin fiilen zayıf olması yasaların uygulanmasına fazla imkan vermemektedir.

\section{Ermenistan'da Bölgesel Politikalar}

\section{Ermenistan'da Bölge}

'Bölge' kavramının, çok yönlü ve farklı boyutlarla tanımlanan bir kavram olduğu açıktır. Özellikle her ülkedeki bölge olgusu, o ülkedeki tarihsel, ekonomik, sosyal, siyasi gelişmelerle ve süreçlerle oluşan, gelişen ve tanımlanan bir olgudur. Bölge "bir ülkenin, doğal güzellikleri, nüfus yapısı, kaynakları, çıkarları açısından türdeşlik gösteren, bir bütün olarak tasarlanmasında yarar görülen bölüm" (Keleş, 1998: 29) veya "kimi ülkelerde, birkaç ili kapsayan yönetsel birim”(TÜBA, 2011: 196) olarak tanımlanabilir. 
Harita 1. Ermenistan İdari Taksimat1

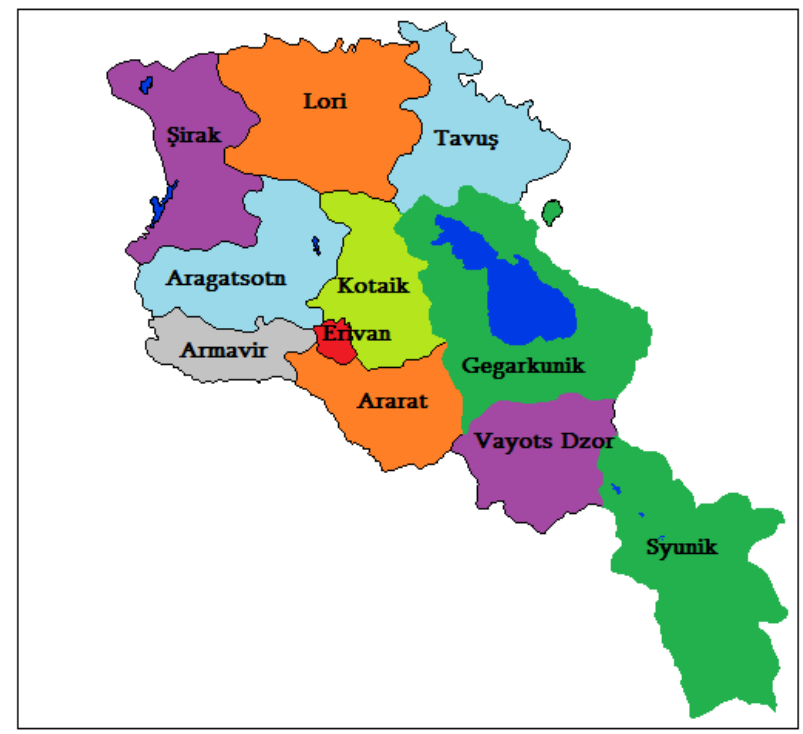

Ermenistan'ın şimdiki idari taksimatı 1995 yılında kabul edilen Anayasayla ve ona göre tasarlanan ve kabul edilen 'Ermenistan Cumhuriyeti İdari Taksimatı Hakkında Kanunu'yla oluşturulmuştur. Anayasaya ve bu kanuna göre Ermenistan 11 bölgeye (Ermenice- Marz) ayrılmıştır. 27 Kasım 2005 tarihinde Ermenistan Anayasası'nda değişiklikler yapılmış ve bu değişikliklere göre eskiden bölge statüsüne sahip olan başkent Erivan belediye statüsü kazanmıştır.

Ermenistan'daki bu bölgeler merkezi yönetimin tek taşra birimleridir. Her bölgede, Ermenistan hükümeti tarafından seçilen bir bölge başkanı (marz başkanı) bulunmaktadır. Erivan ise, 2005 yılından beri belediye statüsüne sahiptir ve orada belediye başkanı halk tarafından seçilmektedir (ilk seçimler 2013 yılında gerçekleştirilmiştir).

Dolayısıyla, Ermenistan'da bölgesel politikalar bu bölgeler çerçevesinde planlanmakta ve gerçekleştirilmektedir. Ermenistan'da bölgesel politikalar bağlamında ilginç bir husus vardır. Bu ülkede merkezi yönetimin tek taşra birimi olan bölgeler (marzlar) coğrafi, tarihsel, ekonomik, sosyal ve diğer açılardan bir bütünlük olarak karşımızda çıkmaktadırlar. Başka bir deyişle, Ermenistan'da coğrafi ve idari bölge yapıları fiilen ve hukuken büyük ölçüde birbiriyle örtüşük durumdadır. Bölgesel gelişme programlarının hazırlanması ve uygulanması açısından bu durum, Ermenistan'a özgü ve çok büyük önem taşıyan bir husustur. Diğer post-Sovyet ülkelerinde olduğu gibi Ermenistan'a özgü diğer önemli bir husus, Ermenistan'ın bölgesel gelişme programları 
hazırlama ve uygulama konusunda Sovyet dönemindeki zengin geleneklere sahip olmasıdır.

\section{Ermenistan'da Bölgelerarası Dengesizlikler}

Ermenistan'ın bölgesel politikalarına değinmeden önce, ülkedeki bölgelerarası dengesizliklere göz atmak yararlı olacaktır. Ekonomik gelişmişlik açısından Ermenistan bölgeleri arasında büyük dengesizlikler bulunduğunu söylemek gerekir. Örneğin, nüfus yoğunluğu açısından merkezi bölgeler (Armavir, Ararat, Kotayk) en yoğun nüfusa sahip olan bölgelerdir, çevrede yer alan bölgeler (Syunik, Tavuş, Gegerkunik) ise bu açıdan ülke ortalamasından (kilometre kareye 102 kişi) daha az nüfus yoğunluğuna sahiptir (ayrıntılı olarak bkz. Harita 2).

Ekonomik verilere bakıldığında, yine benzer farklılıklar görülebilmektedir. Örneğin, kişi başına düşen GSYIH'ya göre bir taraftan Erivan, Syunik, Vayots Dzor bölgeleri en yüksek oranlara sahipken; Tavuş, Şirak, Armavir bölgeleri en düşük gelirlere sahip olan bölgelerdir. Aynı şeyi yoksulluk oranları için de söyleyebiliriz. Örneğin, ülkede ortalama yoksulluk oran1 \%23.5 iken, Erivan, Aragatsotn, Tavuş bölgelerinde bu oran \%19-20'dir. Aynı zamanda Şirak, Kotaik ve Armavir bölgelerinde bu rakam yaklaş1k \%29-30'dur (bkz. Tablo 2 ve Harita 2,3).

Harita 2. Ermenistan'da Bölgelere Göre Nüfus Yoğunluğu

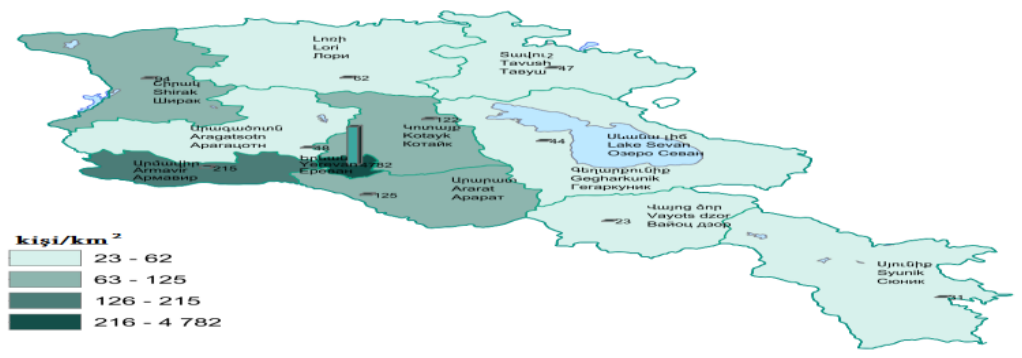

Kaynak: armstat.am, 2003. 
Tablo 2. Ermenistan'da bölgelere göre yoksulluk ve kişi başına düşen GSYİH oranları

\begin{tabular}{|c|c|c|}
\hline Bölge & Yoksulluk oranı(\%) & Kişi başına düşen GSYIH(TL $\left.{ }^{1}\right)$ \\
\hline Erivan & 19.7 & 8402.6 \\
\hline Aragatsotn & 20.7 & 2904.1 \\
\hline Ararat & 24.9 & 2871.7 \\
\hline Armavir & 26.7 & 2699.5 \\
\hline Geğarkunik & 24.8 & 2849.5 \\
\hline Lori & 25.1 & 3222.2 \\
\hline Kotaik & 29.5 & 2973.2 \\
\hline Şirak & 30.6 & 2149.0 \\
\hline Syunik & 20.3 & 7348.5 \\
\hline Vayots Dzor & 21.1 & 5557.2 \\
\hline Tavuş & 19.8 & 1692.8 \\
\hline Toplam & 23.5 & 5053.6 \\
\hline
\end{tabular}

Kaynak: (Ermenistan Bölgesel Gelşime Programı, 2011: 3)

Harita 3. Ermenistan' da bölgelere göre kişi başına düşen GSYİH ${ }^{2}$

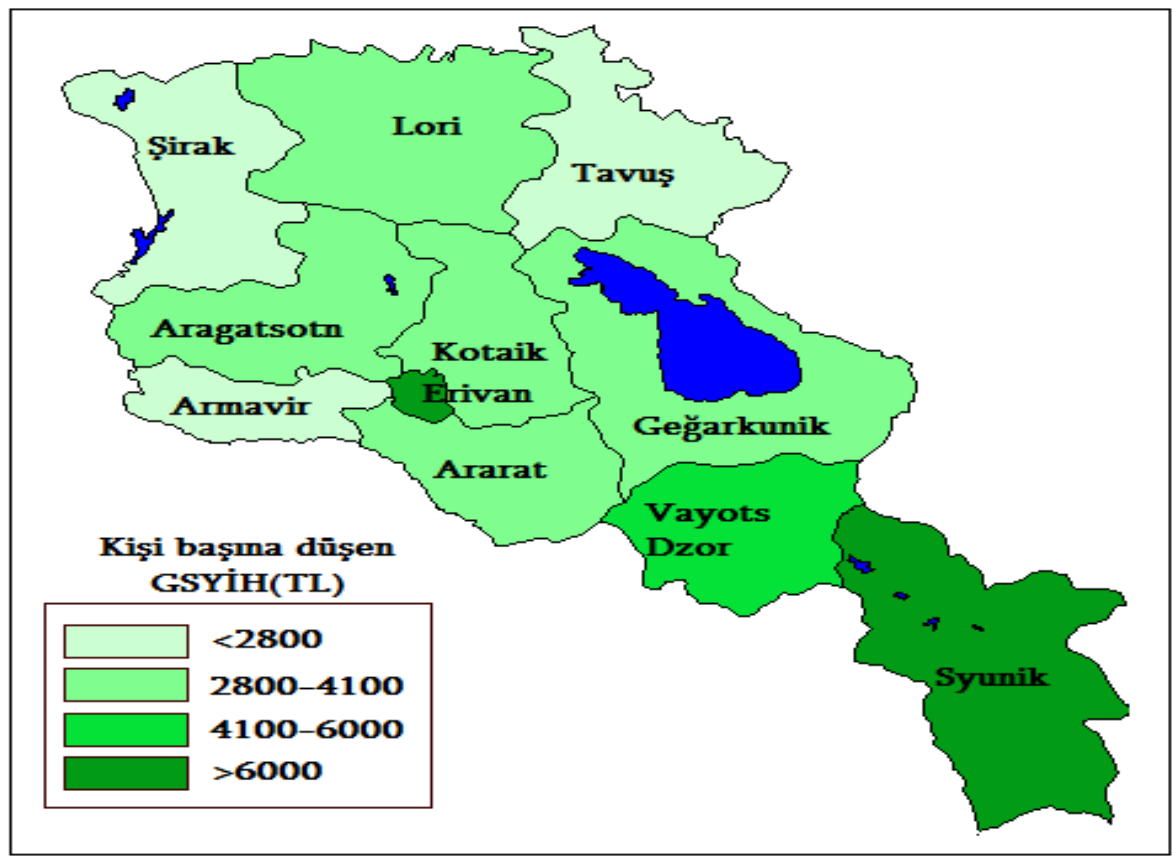

\footnotetext{
8 Asıl kaynakta GSYİH verileri Ermenistan para birimi olan “dram” ile aktarılmış, 1 dram yaklaşık 0.01TL'dir.

${ }^{9}$ Bu harita Tablo 2'nin verileri kullanılarak yazar tarafından hazırlanmıştır.
} 
Harita 4. Ermenistan'da bölgelere göre yoksulluk oranlar1 ${ }^{3}$

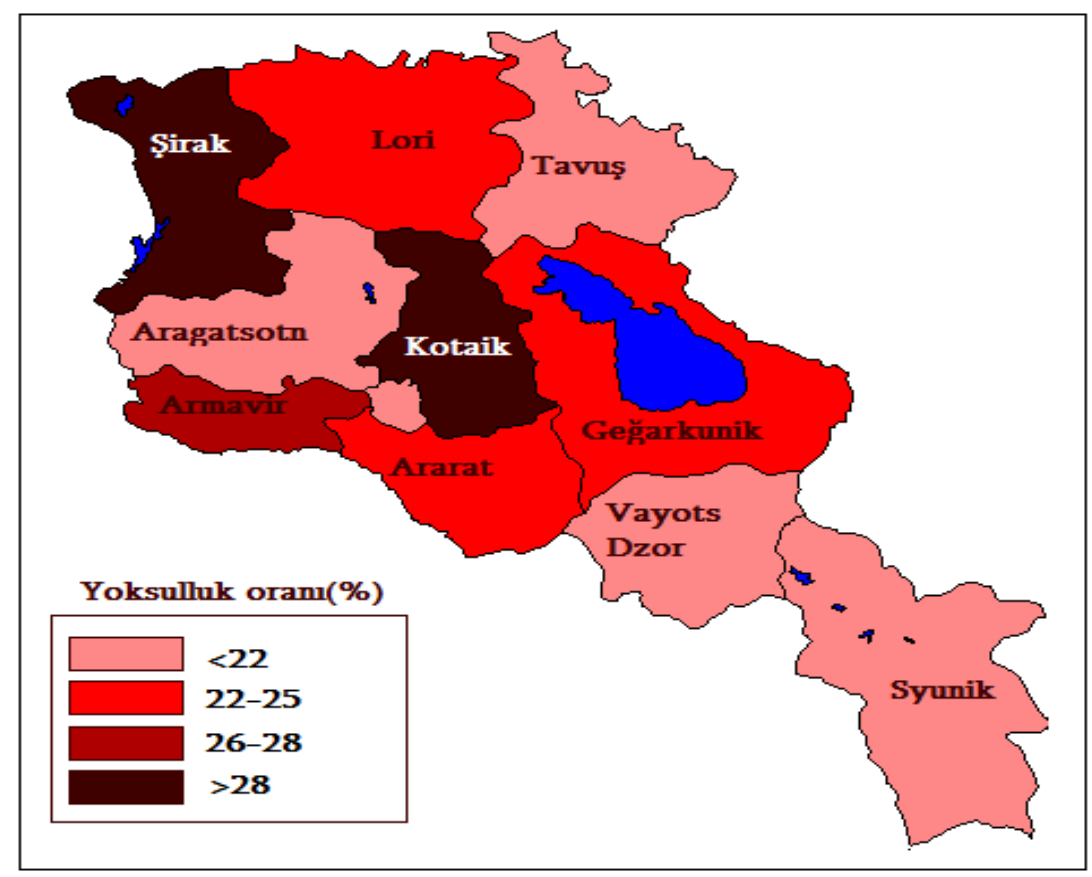

Görüldügü üzere, Ermenistan'da sosyal ve ekonomik açıdan bölgeler arasında büyük dengesizlikler bulunmaktadır. Çalışmanın bu safhasında, bu dengesizlikleri ortadan kaldırma veya azaltmaya yönelik Ermenistan'ın bölgesel politikalarına değinilecektir.

\section{Ermenistan'da Bölgesel Politikalar}

Ermenistan'da bölgesel politikaların geliştirilmesi, planlanması ve gerçekleştirilmesi amaciyla, 27 Nisan 2005 tarihinde Ermenistan Cumhurbaşkanlığı kararıyla Bölgesel Yönetim Bakanlığı kurulmuştur. Fakat bu bakanlığın görevlerinin ve yetkilerinin sadece bölgesel politikaları kapsamadığını belirtmemiz gerekir. Ermenistan Cumhuriyeti'nin Bölgesel Yönetim Bakanlığı Ermenistan hükümetinin politikalarını yürüten organdır. Bakanlığın asıl işlevlerine bakıldığında bölgesel politikalar açısından önemli olan maddeler aşağıdaki gibi sıralanabilir (mta.gov.am, 2014):

1. Ermenistan Cumhuriyeti Hükümetinin bölgesel politikalarının geliştirilmesi ve onların gerçekleştirilmesinin gözetilmesi,

\footnotetext{
${ }^{10} \mathrm{Bu}$ harita Tablo 2'nin verileri kullanılarak yazar tarafindan hazırlanmıştır.
} 
2. Bakanlığın yetkileri arasında bulunan alanlarla ilgili kanun ve diğer yasal düzenlemelerin taslaklarının hazırlaması ve değerlendirme/müzakere için belirlenmiş yönteme uygun olarak Ermenistan Cumhuriyeti Hükümetine ve Ermenistan Cumhuriyetin Başbakanına sunulması,

3. Devletin yürütme organlarından, bölgesel ve yerel yönetim organlarından, hükümetin bölgesel politikalarıyla ilgili gerekli bilgilerin edinilmesi,

4. Ermenistan Hükümetine ve Başbakanına bölgelerin sosyal ve ekonomik durumuyla ilgili gerekli bilgilerin temin edilmesi,

5. Ermenistan Cumhuriyeti'ndeki bölgelerin sosyal ve ekonomik gelişme programlarının değerlendirilmesi ve onaylanması için Ermenistan Hükümeti'ne sunulmas1,

6. Bölgesel ve yerel gelişme projelerinin değerlendirilmesi, uluslararası antlaşma taslaklarının hazırlanması ve uluslararası antlaşmaların imzalanması veya antlaşmalara katılması için önerilerde bulunulması,

7. Yerel yönetim organlarının kendi görevleriyle ve devlet tarafindan devredilmiş görevlerinin yerine getirilmesinin yasal denetimi,

8. Belediye bütçelerinin oluşturulması ve uygulanması sürecinde Ermenistan Cumhuriyeti mevzuatının belirlediği görevlerin yerine getirilmesi,

9. Belediye bütçelerinin uygulanması sürecinin gözlemlenmesi,

10.Bölgesel yönetimlerin (marzpetlerin) kararlarının yasal denetimi ve gerekirse bu kararların iptal edilmesi için başbakana öneriler sunulması.

Ermenistan'da bölgesel politikaların geliştirilmesi ve uygulanması için 30 Haziran 2011 tarihinde Ermenistan Hükümeti tafarından 'Bölgesel Gelişme Programı' onaylanmıştır (Ermenistan Bölgesel Gelşime Programı, 2011). Bu program, Ermenistan'da bölgesel gelişmenin amaçları, sorunları, temel hedefleri ve gelişme araçlarını belirlemektedir. Bu doğrultuda aşağıda bu programdan da yararlanarak, gelişmenin amaçlarına, hedeflerine ve araçlarına değinilecektir. Burada bu programın kullanılmasının temel sebebi, programın Ermenistan hükümetinin bölgesel politikalarını yansıtan resmi bir belge olmasıdır.

\section{Bölgesel Gelişmenin Amaçları}

Ermenistan Hükümetinin bölgesel gelişme politikalarının amaçları şunlardır (Ermenistan Bölgesel Gelşime Program1, 2011: 9-10):

1.Rekabet edebilir ve çekici bölgelerin oluşturulması. Özellikle:

a) Girişimciliği teşvik etmek amacıyla endüstriyel altyapıların (yollar, ulaşım, telekomünikasyon, vs.) oluşturulması ve geliştirilmesi, ayrıca bölgelerde sunulan kamu hizmetlerine (eğitim, sağlık, kültürel vs.) ulaşılabilirliğin artırılması ve etkililiğinin yükseltmesi, 
b)Bölgelerin karşılaştırmalı üstünlüklerinin ticarileştirilmesi; bunun gerçekleştirilmesi için devlet, bölgesel ve yerel yönetim organlarının çabalarının birleştirilmesi ve özel sektörün sürece dahil etmesi,

c)Bölgelerde tarım sektörünün modernizasyonu ve köylerdeki sorunların çözülmesi,

2.Bölgesel ve yerel yönetim organlarının kurumsal kapasitelerin güçlendirilmesi:

a)Bölgesel gelişme için, bölge tarafindan kendi endüstriyel ve diğer kamu fonksiyonlarının gerçekleştirilmesi ve bu yönelime uygun sosyo-ekonomik koşulların yaratılması,

b)Bölgelerde tarımın verimliliğinin artırılması ve ülke ekonomisinde tarım kesiminin istikrarlı olarak büyümesinin sağlanması,

c)Bölgelerde yaşayan nüfusun yaşam kalitesinin, refahının, istihdam oranlarının yükseltilmesi, ayrıca bölgelerdeki nüfusun yaşam standartlarının Erivan şehrinin standartlarına yakınlaştırılması,

ç) Bölgelerden göçün azatılması ve kır nüfusu sayısının dengelenmesi,

d)Bölgelerarası ve bölgeler içinde yaşam kalitesi ve rafah farlılıklarının azaltılmas1.

\section{Bölgesel Gelişme Sorunları}

Ermenistan hükümetinin bölgesel gelişme politikalarının sorunları şu şekilde sıralanabilir (Ermenistan Bölgesel Gelşime Programı, 2011: 10):

1.Bölgelerin uyumlu gelişmesi: Erivan şehri ve bölgeleri, ayrıca bölgeler arasında var olan yaşam standartı farklılıkların azaltılması ve bölgelerin gelişim hızının Erivan'ınkinine yakınlaştırılması,

2. Bölgelerin rekabet edebilirliğinin yükseltmesi: bölgelerin ekonomik gelişme sorunlarının çözümü ve ihtiyaçlarının karşılanması için bölgelerde var olan kaynakların mukayeseli üstünlüklerinin ortaya çıkarılması, onlardan yararlanılması için gerekli koşulların yaratılması,

3.Bölgelerde ekonominin çeşitlendirilmesi ve kırsal nüfusun gelir kaynaklarının genişletilmesi,

4.Konut koşulların iyileştirilmesi,

5.Sosyal, teknik, ulaşım, telekomünikasyon ve diğer altyapıların modernleştirilmesi.

\section{Bölgesel Gelişimin Temel Doğrultuları}

Ermenistan hükümetinin bölgesel gelişme politikalarının temel doğrultuları şu şekilde sıralanabilir (Ermenistan Bölgesel Gelşime Programı, 2011: 10-12): 
1. Kamu yatırımları için değerlendirme sisteminin yaratılması ve bu sistemde bölgesel boyuta vurgu yapılmas1,

2. Ermenistan Cumhuriyeti devlet bütçesinden sağlanan yatırımlar içinde Erivan'dan bölgelere yapılan yatırımların payının yükseltilmesi,

3. Bölgelerdeki yatırımların ve bölgelere verilen tahsisatların, desteklerin ve hibelerin verimliliğinin artırılması,

4. Hedefe yönelik programların gerçekleştirilmesi (gelişim merkezleri oluşturma projeleri, afet bölgesinin ${ }^{4}$ ve başka afetlerden dolayı ortaya çıkmış sorunların çözümüne yönelik projeler vs.)

5. Belediyelerin birleştirilmesi ve belediyelerarası birliklerin oluşturulması,

6. Tarımın geliştirilmesi, tarım amaçlı toprakların birleştirilmesi,

7. Rekabet edilebilir ve çekici yerlerin (gelişme merkezleri) belirlenmesi, bu yerlerin gelişme potansiyelinin değerlendirilmesi,

8. Devlet desteklerinin bölgelere yönlendirilmesi, bu desteklerin özellikle yoksulluğu azaltmada en etkili olan sorunların çözümüne yönlendirilmesi,

9. Yeni iş yerlerinin açılması ve yüksek istihdamın sağlanması.

\section{Ermenistan'da Bölgesel Gelişme Politikalarının Araçları}

Ermenistan Hükümeti bölgesel politikalarının araçları kendi tür ve etkilerine gore altı temel gruba ayrılmaktadır (Ermenistan Bölgesel Gelşime Programı, 2011: 12-13):

Planlama: Planlama, bölgelerin sosyo-ekonomik durumu hesaba kat1larak yapılmaktadır. Planlamanın nasıl ve neye göre yapılacağı ise hükümet tarafindan onaylanmış Bölgesel Gelişme Programı'nda ek olarak detaylı bilgiler verilmektedir (Ermenistan Bölgesel Gelşime Program1, 2014: 15-24).

Finansal teşvikler: Şimdiye kadar bölgesel gelişmeye yönelik Ermenistan Hükümeti tarafından gerçekleştirilmiş finansal projeler:

-Kredi projeleri,

-Sektörel gelişmeye yönelik devlet projeleri,

- Garanti projeleri,

- Kamu kesim-özel kesim işbirliğine dayalı projeler.

Bilgi toplama ve danışmanlık: Programın bilgi/veri altyapısı Ermenistan Cumhuriyeti Milli İstatistik Müdürlüğü'nün yayınları, devlet bütçeleri ve onların uygulamalarınca oluşturulacaktır.

\footnotetext{
11 “Afet bölgesi” 7 Kasım 1988 tarihinde Ermenistan'ın kuzeyinde (özellikle Şirak ve Lori bölgeleri kapsayan) ortaya çıkmış depremin etkilediği bölgelerdir.
} 
Ayrıca, bu programa göre oluşturulan projelerde AB'nden sağlanan teknik yardımlardan ve danışmanlık için AB uzmanlarından yararlanılacaktır. Ayrıca projelerin gerçekleştirilmesi için AB'nin bölgesel politikalar alanında faaliyette bulunan fonlarından mali destek almak için önlemler alınacaktır.

Altyapılar için destek: Yoksulluğun değiştirilmiş indeksine göre desteğe gerek duyulan altyapılar belirlenecek ve ona göre bu altyapılara destek verilecektir.

Ídari faaliyetler: Kamu açısından önemli projeler, bölgesel ve yerel yönetimlerin katılımıyla ve desteğiyle oluşturulacaktır. Ermenistan Cumhuriyeti bölgelerinin (marzların) gelişme programlarının artık böyle bir yaklaşımla oluşturulacağı hükümet tarafından onaylanmıştır.

Bölgesel gelişme fonu: Şimdiye kadar faaliyette bulunan Küçük ve Orta Girişimci Kurumlar Fonu'nun, Kırsal Bölgelerin Ekonomik Gelişme Fonu'nun örnekleri göz önünde bulundurularak 'Bölgesel Gelişme Fonu' denilen kuramsal bir yapının oluşturmasının uygunluğunun yasal temelleri ve imkanları incelenecektir. Bölgesel Gelişme Fonu'nun amacı bölgelerde altyapıların (konut, yollar vs.) oluşturulması, bakımı ve bölgesel gelişme merkezlerinde girişimciliğin teşvik edilmesi için piyasa oranlarından daha düşük oranlarla kredilerin sağlanmasıdır.

Son olarak belirtmemiz gerekir ki Ermenistan hükümetinin bölgesel gelişme programına göre her bölge için 4 yıllık gelişme programları hazırlanmakta ve uygulanmaktadır. Şu an yürürlükte olan bu programlar genellikle 2014-2017 y1lları arasını kapsamaktadır (mta.gov.am, 2014).

\section{Sonuç}

Sonuç olarak, Avrupa Yerel Yönetimler Özerklik Şartı'nın ilkelerinin çoğu Ermenistan yerel yönetimler mevzuatına yansıdığg söylenebilir. Aynı zamanda Ermenistan, Avrupa Yerel Yönetimler Özerklik Şartı'nda bulunmayan fakat bu Şart'a aykırı olmayan, kendi yerel yönetim sistemine özgü ilkeler de benimsemiştir. Ermenistan Cumhuriyeti'nde yerel yönetimler mevzuatı ise genel olarak Avrupa Yerel Yönetimler Özerklik Şartı'ndaki maddelere uyum sağlamaktadır. Buna karşınэ Ermenistan mevzuatında çok sayıda eksiklikler bulunmaktadır ve yıllardır bunlara çözüm bulunmamıştır. Zira çözüm için ciddi ve hedeflenmiş faaliyetler gerçekleştirilmemektedir. $\mathrm{Bu}$ bağlamda, Ermenistan'da diğer önemli sorun, yerel yönetimlerin merkezi hükümet ile yerel yönetimler arasındaki güç paylaşımında fiilen çok zayıf olmasıdır. Dolayısıyla, AYYÖŞ’ün ilkeleri ne kadar Ermenistan mevzuatına yansımış ve yerel yönetimlerin yetki genişliği tanınmış olsa da, yerel yönetimlerin fiilen çok zayıf olması (ki bu durum Ermenistan'ın demokratikleşme süreçleri ile bağlantılı bir olgudur) çoğu kez yasaların uygulanmasına fazla imkan vermemektedir. 
Ermenistan'da konu ile ilgili diğer önemli husus ise, Türkiye ile karşılaştırdığımız zaman Şart'ın Türkiye tarafından çekince konulan maddelerin çoğuna Ermenistan'ın da ya çekince koymuş ya da açık şekilde çekince koyduğunu dile getirmeden mevzuatında Şart'in ilgili maddelerine uyum sağlamaktan kaçınmış olmasıdır.

Bölgesel politikalar bağlamında bu ülkede bölgelerarası büyük dengesizlikler bulunmaktadır ve bu dengesizlikleri ortadan kaldırmak için hazırlanmış ve uygulanmakta olan bölgesel gelişme projeleri de söz konusudur. Hatta 2005 yılından beri bölgesel gelişme konularında yetkili bir bakanlık da, Bölgesel Yönetim Bakanlığı, bulunmaktadır. Fakat belirtilmelidir ki Ermenistan, bölgesel gelişme projeleri hazırlamak ve onları uygulamak için çok sayıda avantaja sahip olmasına rağmen, özellikle Sovyet dönemi planlama pratiklerinin zengin geleneklerine sahip olmasına, coğrafi ve idari bölgelerin büyük ölçüde birbiriyle örtüşük olmasına ve geçen dönemlerde uygulamaya konulmuş olan bölgesel gelişme projelerine rağmen, ülkede var olan bölgelerarası dengesizlikler daha da derinleşmektedir.

\section{Kaynakça}

Akelyan, Anna (2011), Armenian Government Commitments to Decentralization Policy and Development of Local Self-Governance, Unpublished Master Thesis, American University of Armenia, the Faculty of the Graduate School of Political Science and International Affairs, Yerevan.

Avrupa Yerel Yönetimler Özerklik Şartı, Resmi Gazete, 3 Ekim 1992, Sayı 21364.

Babajanian, Babken (2008a), Decentrilized Government in Post-Soviet Armenia, NGPA Working Paper Series, London School of Economics.

Babajanian, Babken (2008b), "Local Governance in Post-Soviet Armenia: Leadership, Local Development and Accountability, Communist and Post-Communist Studies 41", s. 375-396

Charter of "The Staff and the Structure of Ministry of Territorial Administration" of the Republic of Armenia, http://www.mta.gov.am/en/charter/ (12.12.2014).

Choginyan, Grigor (2007), Strenghtening Local Governments in Armenia, Unpublished Master Thesis, Central European University, Department of Public Policy, Budapest.

Doane J. - Simpson M. - Robenhorst C. (2000), Baseline Study for Armenia Local Government Program, The Urban Institute, Washington.

Dudarev V. A. - Evseeva N. A. (Der.) (1987), SSSR: Administrativno-territorialnoye deleniye soyuznix respublik, Izvestiya Sovetov narodnix deputatov, Moskova.

Ermenistan Bölgesel Gelşime Programı (2011), http://www.mta.gov.am/u_files/file/Hayecakarger/MAR2538_1\%D5\%BF\%D5\%A1\%D6\%80\%D5\%A1\%D6\%81\%D6\%84\%D5\%A1\%D5\%A B\% D5\%B6- 
\%D5\%B0\%D5\%A1\%D5\%B5\%D5\%A5\%D6\%81\%D5\%A1\%D5\%AF\%D5\%A1\% D6\%80\%D5\%A3.pdf (20.12.2014).

Ermenistan Cumhuriyeti Denetleme Odası Hakkında Kanunu

http://www.parliament.am/legislation.php?sel=show \&ID=2835\&lang=arm\&enc=utf 8 (13.12.2014).

Ermenistan Cumhuriyeti İdari Taksimat Hakkinda Kanunu http://www.parliament.am/legislation.php?sel=show\&ID=2243\&lang=arm (13.12.2014).

Ermenistan Cumhuriyeti Katı Atıklar Hakkında Kanunu http://parliament.am/legislation.php?sel=show\&ID=2136 (13.12.2014).

Ermenistan Cumhuriyeti Okul Öncesi Eğitim Hakkında Kanunu http://edu.am/index.php?id=89\&topMenu=-1\&menu $1=85 \&$ menu $2=89 \& \operatorname{arch}=0$ (13.12.2014).

Ermenistan Cumhuriyeti Şehircilik Hakkında Kanunu http://www.parliament.am/legislation.php?sel=show\&ID=1953\&lang=arm\&enc=utf 8 (14.12.2014).

Hovasapyan, Elina (2005), The Rule of Local Self-Governance in Armenia: Past Experience and Challenges, Unpublished Master Thesis, American University of Armenia, The Faculty of the Graduate School of Political Science and International Affairs, Yerevan.

Keleş, Ruşen (1998), Kentbilim Terimleri Sözlüğü, İmge Kitabevi, Ankara.

Keleş, Rüşen-Mengi, Ayşegül (2013), Avrupa Birliği'nin Bölge Politikaları, Cem Yayınevi, 1. Basım.

Local Self-Government in Armenia: 2004-2006 (2008), Materials of National Conference, Book 2, Tumanyan D.(ed.), Yerevan.

Local Self-Government in Armenia: 2009 and 2010 (2011), Book 4, Tumanyan D. (ed.), Yerevan.

Maliye Ayarlama Hakkında Ermenistan Cumhuriyeti Kanunu (Ermenice metni) http://www.parliament.am/legislation.php?sel=show\&ID=1956\&lang=arm (14.12.2014).

Margaryan, Tatevik (2011), Phenomena of Informal Relations in the System of Local Self-Government in Armenia, in Changing Identities: Armenia, Azerbaijan, Georgia ; Collection of Selected Works, Heinrich Boell Foundation South Caucasus Regional Office, s. 222-245, Tbilisi.

Saroyan, Zaruhi (2010), Local Governance in Armenia, Unpublished Master Thesis, Central European University Department of Public Policy, Budapest.

The Constitution of the Republic of Armenia (with amendments), http://www.parliament.am/parliament.php?id=constitution\&lang=eng (14.12.2014). 
The Law of the Republic of Armenia on Local Self-Government http://www.parliament.am/legislation.php?sel=show\&ID=1305\&lang=eng (14.12.2014)

The Law of the Republic of Armenia on Taxes http://www.parliament.am/legislation.php?sel=show\&ID=1837\&lang=eng (14.12.2014).

Tumanyan, David (2001a), "Local government in Armenia", I. Munteanu, V. Popa(Ed.), Developing New Rules in the Old Environment: Local Governments in Eastern Europe, Caucasus and Central Asia, LGI Books, s. 323-369, Budapest.

Tumanyan, David (2001b), Politico-Administrative Relations in Armenian Local

Government, $9^{\text {th }}$ NISPAcee Conference, Riga, Latvia, May 10-12 http://unpan1.un.org/intradoc/groups/public/documents/nispacee/unpan009154.pdf (10.12.2014).

TÜBA (2011), Türkçe Bilim Terimler Sözlüğü(Sosyal Bilimler), Ankara.

( http://www.armstat.am/file/doc/99479963.pdf, 12.12.2014 )

( http://mta.gov.am/hy/qaramya, 12.12.2014 ) 